SHORT COMMUNICATION

\title{
Evidence of mutagenic and lethal effects of herbicides on Amazonian frogs
}

\author{
Lucas FERRANTE ${ }^{1, *} \odot$, Philip M. FEARNSIDE ${ }^{2}$ \\ ${ }^{1}$ Instituto Nacional de Pesquisas da Amazônia (INPA), Programa de Pós-Graduação em Ecologia, Av. André Araújo 2936, CEP 69067-375, Manaus, Amazonas, Brazil \\ ${ }^{2}$ Instituto Nacional de Pesquisas da Amazônia (INPA), Coordenação de Dinâmica Ambiental, Av. André Araújo 2936, CEP 69067-375, Manaus, Amazonas, Brazil \\ *Corresponding author: lucasferrante@hotmail.com; (D) https://orcid.org/0000-0003-2636-5713
}

\begin{abstract}
Amphibians are excellent bioindicators because they are sensitive to chemical pollution and can indicate ecosystem changes due to the presence of or exposure to chemical compounds. Here we report evidence of the impact of herbicides, including glyphosate, on amphibians in a locality in the central Brazilian Amazon and compare it with data from other biomes in Brazil. We observed malformations in three species of Leptodactylus and local extinctions of Scinax ruber and Rhinella marina from reproductive sites close to an area where herbicides had been applied. The observations in the Amazon are similar to reports from Brazil's Atlantic forest on morphological anomalies and mortality in amphibians exposed to herbicides. We warn of the threat of expanding crops for the production of biofuels in the Amazon due to their cultivation being associated with agrochemicals, including glyphosate, posing a threat to the biodiversity of the Amazon biome.
\end{abstract}

KEYWORDS: agrochemicals, Amazon Forest, anurans, bioindicators, ecotoxicology, environmental impact

\section{Evidências de efeitos mutagênicos e letais de herbicidas em sapos da Amazônia}

\section{RESUMO}

Os anfíbios são ótimos bioindicadores porque são sensíveis à poluição química, indicando alteraçóes ecossistêmicas pela presença de ou pela exposição a compostos químicos. Aqui nós relatamos evidências do impacto de herbicidas, incluindo glifosato, em anfíbios em uma localidade na Amazônia central brasileira e as comparamos com dados de outros biomas no Brasil. Nós observamos malformaçóes em três espécies de Leptodactylus e extinção local de Scinax ruber e Rhinella marina em sítios reprodutivos próximos a uma área onde herbicidas haviam sido aplicados. Os resultados observados na Amazônia são semelhantes aos observados na Mata Atlântica do Brasil, com alteraçôes morfológicas e mortalidade em anfíbios expostos a herbicidas. Alertamos para a ameaça de expansão de culturas para a produção de biocombustíveis na Amazônia, devido ao fato de o cultivo estar associado a agroquímicos, incluindo o glifosato, representando uma ameaça à biodiversidade do bioma Amazônia.

PALAVRAS-CHAVE: agrotóxicos, anuros, bioindicadores, ecotóxicologia, floresta amazônica, impacto ambiental

Ecotoxicological research on the harmful effects of agricultural chemicals on fauna is necessary given the expansion of crops associated with the use of these products (Schiesari and Grillitsch 2011). Agricultural landscapes can harbor many amphibian species (e.g., Ferrante et al. 2017), which tend to respond negatively to agricultural chemicals at different life stages, such as tadpoles (Orton and Routledge 2011) or post-metamorphics (Brühl et al. 2013). Their sensitivity to pesticides makes amphibians good bioindicator organisms (Gonçalves et al. 2017). The influence of agriculture on these animals is so strong that entire anuran assemblages within forest fragments are influenced by the type of agricultural crops around the fragments (Ferrante $e t$ al. 2017; Ferrante et al. 2019). Here we report evidence of the effect of herbicides, including glyphosate, on anurans on a farm in the central Brazilian Amazon.

All observations were made at the experimental farm of Universidade Federal do Amazonas - UFAM (2³9'15.98”S, $\left.60^{\circ} 3^{\prime} 16.09^{\prime} \mathrm{W}\right)$, in the municipality of Manaus, Amazonas state. The observations are part of a study on amphibians conducted in four deforested areas with a predominance of grasses. The areas were close to artificial ponds that had been installed for pisciculture (Figure 1). The study consisted of eight three-night visual-encounter surveys (Crump and Scott 


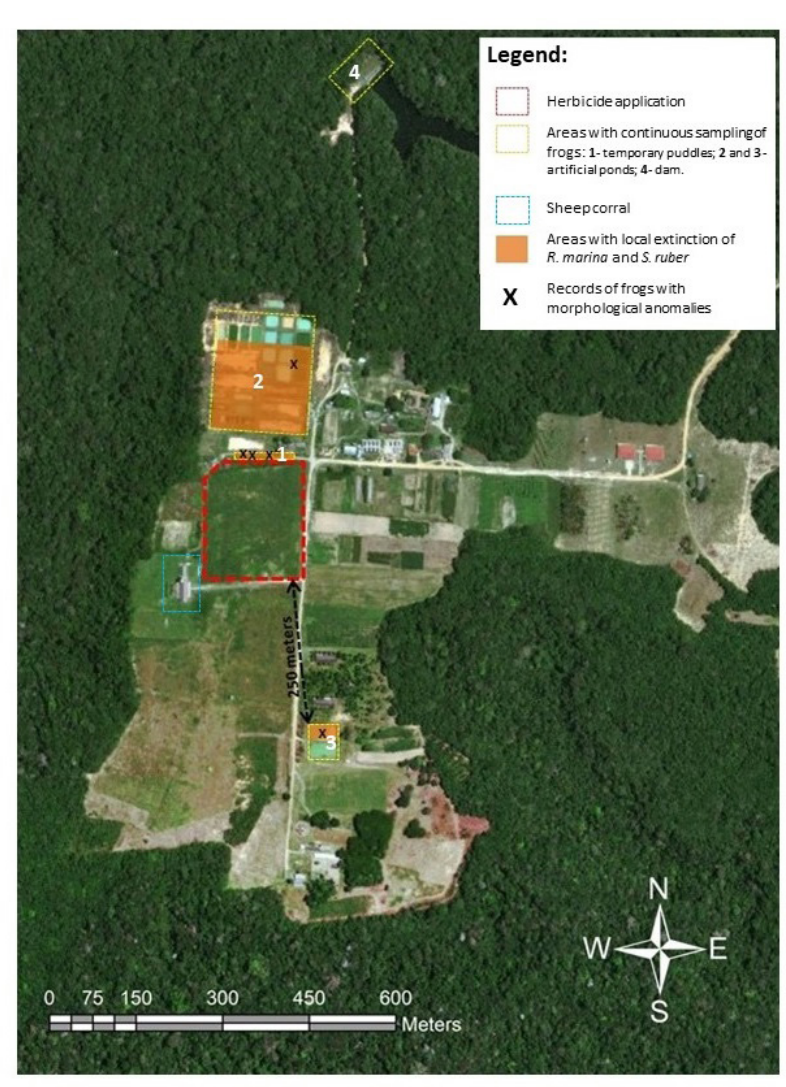

Figure 1. Study area of amphibian surveys in the UFAM farm, in the municipality of Manaus, central Amazonia, Brazil. This figure is in color in the electronic version.

1994). The eight surveys were carried out from July 2016 to March 2018 at intervals of at least three months. On each occasion, two people surveyed each area for two hours each night. The observations reported here were made in March 2018. Two specimens with morphological anomalies were collected under the authorization of license \# 61903-2 issued by Instituto Chico Mendes de Conservação da Biodiversidade (ICMbio), and were deposited in the herpetological collection of Instituto Nacional de Pesquisas da Amazônia (INPA) as voucher specimens (INPA-H039761 and INPA-H039763).

According to the technicians responsible for the farm, six months prior to the observations, a 3.6-ha area of pasture close to our sampling sites and a nearby sheep corral were sprayed with $2 \mathrm{~L}$ of glyphosate (Roundup ${ }^{\oplus}$ ) at a dosage of $200 \mathrm{~mL}$ per $20 \mathrm{~L}$ of water. The pasture was also sprayed with $120 \mathrm{~mL}$ of Disparo ${ }^{\oplus}$, a herbicide containing 2,4-D and Picloram, at a dosage of $60 \mathrm{~mL}$ per $20 \mathrm{~L}$ of water. A 0.5 -ha area of the pasture that was cultivated to produce silage was sprayed with $1 \mathrm{~L}$ of Select $240 \mathrm{EC}^{\oplus}$, a herbicide containing Cletodim and Alquilbenzene, at a dosage of $35 \mathrm{~mL}$ per $20 \mathrm{~L}$ of water. According to the instructions for the three products, Roundup ${ }^{\circledast}$ is "moderately toxic" and Select 240 EC $^{\circledast}$ and Disparo ${ }^{\circledR}$ are "extremely toxic." All have classifications ranging from "potentially hazardous" to "Class III," that is, products that are dangerous to the environment.

On 1 March 2018, during the first survey after the herbicide application, we observed the absence of two anuran species and found individuals with malformations in areas where amphibians had been continuously monitored since July 2016. Five individuals with malformations were found in temporary puddles and a pond, respectively 2 and 250 $\mathrm{m}$ from the pasture area where herbicides had been applied (Figure 1, areas 1 and 3). The individuals with malformations belonged to three Leptodactylidae species: Leptodactylus fuscus (Figure 2), L. macrosternum and L. podicipinus (Figure 3). Three individuals of $L$. fuscus and one of $L$. macrosternum had brachydactyly (digit shortened) (Figure 2). One individual of L. podicipinus had microphtalmia (one small eye) (Figure 3). In one other area further away from the areas where herbicides were applied we found the same species, but without any anomalies (Figure 1, area 4).

The two absent species were Scinax ruber (Hylidae) and Rhinella marina (Bufonidae), both of which had been found to be abundant in the same area in all other surveys since 2016 (Figure 1). In all surveys before herbicide application, more than 150 individuals of $R$. marina (see Ferrante et al. 2020) and approximately 100 individuals of $S$. ruber (L. Ferrante, personal observation) were recorded in areas of temporary puddles and artificial ponds (area 1,2 and 3 in Figure 1). The absence of these species in more than $250 \mathrm{~m}$ from the area of herbicide application (area 3 in Figure 1) is consistent with the results of a controlled study by Carvalho et al. (2019),

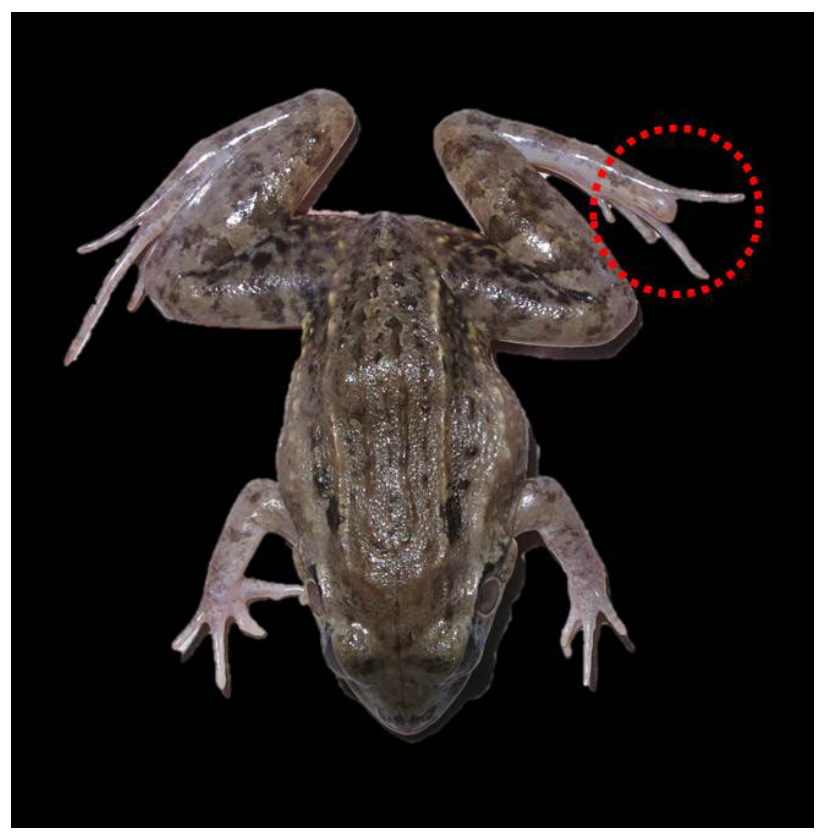

Figure 2. Individual of Leptodactylus fuscus showing brachydactyly (digit shortened) observed at the UFAM farm in Manaus, in central Brazilian Amazonia. This figure is in color in the electronic version. 


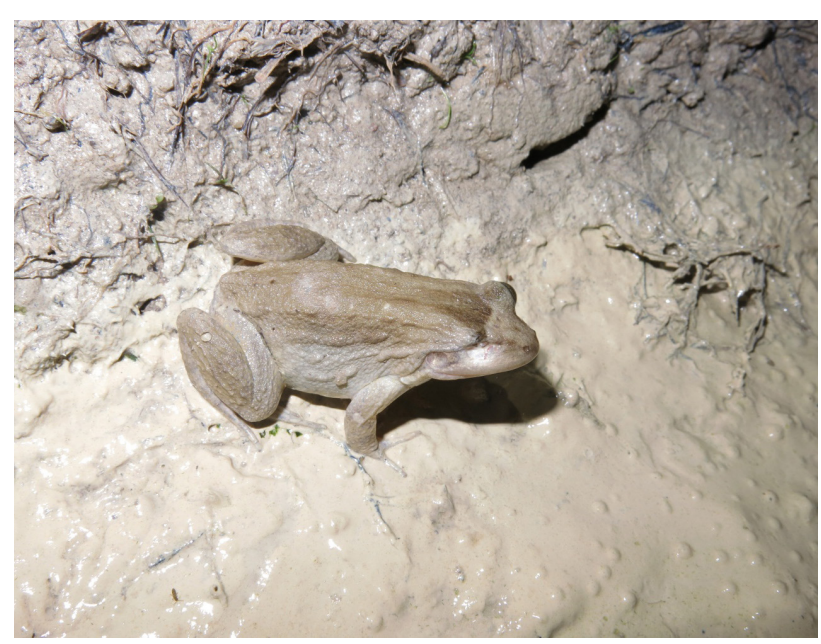

Figure 3. Individual of Leptodactylus podicipinus showing microphtalmia (small eye) observed at the UFAM farm in Manaus, in central Brazilian Amazonia. This figure is in color in the electronic version.

which demonstrated the lethality of glyphosate on tadpoles of Rhinella arenarum. It is also consistent with the findings of Ferrante et al. (2019), who documented the local extinction of Scinax caldarum in over $85 \%$ of its original range in the Atlantic Forest, likely caused by herbicide and pesticide use. Although there are records in the northern hemisphere of malformations in amphibians caused by parasites or by the interaction of parasites with pesticides (Haas et al. 2017), the parasite that causes such anomalies (Ribeiroia ondatrae) is restricted to the northern hemisphere. This suggests that the malformations we observed were caused by the herbicides that were applied, as has been observed in various other studies of amphibian malformations (e.g., Ouellet et al. 1997; Lannoo 2008; Egea-Serrano et al. 2012; Wagner et al. 2013; Sparling et al. 2015; Koleska and Jablonski 2016; Mônico et al. 2019). Amphibians have high philopatry and low vagility (Wells 2007), making it possible to map the impact of herbicides on the landscape through the occurrence of individuals with malformations and the absence of species that were previously abundant. In addition, the absence of certain species even six months after herbicide application demonstrates the longterm persistence of effects on amphibian populations. Based on the shortest distance between the sprayed field and the sampled areas where no malformations or local extinctions were observed, we can conclude that the impact radius of these herbicides did not exceed $300 \mathrm{~m}$.

Alternative hypotheses fail to explain the presence of individuals with morphological anomalies exclusively in proximity to the target area of the agrochemicals, while all individuals of the same species in more distant areas appeared healthy. The occurrence of malformations in three species that are abundant throughout the landscape rules out the possibility of morphological effects linked to population phenomena, as has been observed for anuran populations with genetic erosion due to inbreeding (Bessa-Silva et al. 2016).

Our observations are similar to the impacts observed in other biomes in Brazil, such as those in the Atlantic Forest discussed by Ferrante et al. (2019). Forest fragments in the Atlantic Forest surrounded by large areas of crops such as sugarcane and coffee, with intensive use of glyphosate and other agrochemicals, harbor a low diversity of anuran generalist species that use both the agricultural area and the remaining forest (Ferrante et al. 2017). Among these species were Leptodactylus fuscus, Leptodactylus latrans and Scinax fuscovarius, which belong to the ruber group (see Ferrante et al. 2017: Table 1 and Figure 2b).

In central Amazonia vegetable producers in the lowland areas along the great rivers do not follow the recommendations provided in the inserts that are included in the packaging of agricultural chemicals, and dozens of agrochemicals are used at higher doses than suggested by their manufacturers (Schiesari et al. 2013). The areas close to rivers and streams that are preferred for vegetable production are also of vital importance to amphibian conservation, including many species that occur exclusively in these habitats and depend on the protection of the remaining natural vegetation (Moraes et al. 2016).

In 2019 alone, the Brazilian government allowed use of at least 474 new agrochemicals, many of which are banned in other countries (Ferrante and Fearnside 2019). The doses used in Brazil are up to 5000 times greater than those recommended by European environmental agencies (Ferrante and Fearnside 2019). The Amazon faces one of its most critical moments due to pressure from Brazilian agribusiness and its impact on the forest and biodiversity (Ferrante and Fearnside 2019). Expansion of biofuel crops represents a new threat to the biome (Ferrante and Fearnside 2020), and these crops are already a major threat to biodiversity in biomes such as the Cerrado (central Brazilian savanna) due to use of agrochemicals (Schiezari and Grillitsch 2011; Schiezari et al. 2013). Glyphosate and other herbicides used in sugarcane and corn plantations in Brazil have been shown to be lethal to amphibians, regardless of species (Wagner et al. 2013; Daam et al. 2019). Our data suggest that the expansion of agricultural crops in the Amazon, as biofuels crops and the dependence of these crops on glyphosate and other herbicides could have devastating effects on biodiversity in the region.

\section{ACKNOWLEDGMENTS}

We thank UFAM's Experimental Farm for the logistical support for this study. LF thanks Conselho Nacional de Desenvolvimento Científico e Tecnológico - CNPq for the resources that made it possible to carry out this sampling, and Thainá Najar for help in the field. Thanks to Claudia Keller for constructive comments on this manuscript. 


\section{REFERENCES}

Bessa-Silva, A.R.; Vallinoto, M.; Sodré, D.; Cunha, D.B.; Hadad, D.; Asp, N.E.; Sampaio, I.; Schneider, H.; Sequeira, F. 2016. Patterns of genetic variability in island populations of the cane toad (Rhinella marina) from the mouth of the Amazon. PLoS ONE 11: e0152492.

Brühl, C.A.; Schmidt, T.; Pieper, S.; Alscher, A. 2013. Terrestrial pesticide exposure of amphibians: An underestimated cause of global decline? Scientific Reports, 3: 1135. https://doi.org/.1038/ srep01135

Carriquiriborde, P.; Mirabella, P.; Waichman, A.; Solomon, K.; Brink, P.J.V.; Maund, S. 2014. Aquatic risk assessment of pesticides in Latin America. Integrated Environmental Assessment and Management, 10: 539-542.

Carvalho, W.F.; Arcaute, C.R.; Pérez-Iglesias, J.M.; Laborde, M.R.R.; Soloneski, S.; Larramendy, M.L. 2019. DNA damage exerted by mixtures of commercial formulations of glyphosate and imazethapyr herbicides in Rhinella arenarum (Anura, Bufonidae) tadpoles. Ecotoxicology, 28: 367-377.

Crump, M.L.; Scott, N.J. 1994. Visual encounter surveys. In: Heyer, W.R.; Donnelly, M.A.; McDiarmid, R.W.; Hayek L.A.; Foster, M.S. (Ed.). Measuring and Monitoring Biological Diversity. Standard Methods for Amphibians. Smithsonian Institution Press, Washington D.C., p.84-92.

Daam, M.A.; Moutinho, M.F.; Espíndola, E.L.G.; Schiesari, L. 2019. Lethal toxicity of the herbicides acetochlor, ametryn, glyphosate and metribuzin to tropical frog larvae. Ecotoxicology, 28: 707-715.

Egea-Serrano, A.; Relyea, R.A.; Tejedo, M.; Torralva, M. 2012. Understanding of the impact of chemicals on amphibians: a meta-analytic review. Ecology and Evolution, 2: 1382-1397.

Ferrante, L.; Baccaro, F.B.; Ferreira, E.B.; Sampaio, M.F.O.; Santos, T.; Justino, R.C; Angulo, A. 2017. The matrix effect: How agricultural matrices shape forest fragment structure and amphibian composition. Journal of Biogeography, 44: 1911-1922.

Ferrante, L.; Fearnside, P.M. 2019. Brazil's new president and "ruralists" threaten Amazonia's environment, traditional peoples and the global climate. Environmental Conservation, 46: 261-263.

Ferrante, L.; Fearnside, P.M. 2020. The Amazon: biofuels plan will drive deforestation. Nature, 577: 170.

Ferrante, L.; Leonel, A.C.M.; Gaiga, R.; Kaefer, I..L.; Fearnside, P.M. 2019. Local extinction of Scinax caldarum, a tree frog in Brazil's Atlantic forest. Herpetological Journal, 29: 295-298.

Ferrante, L.; Najar, T.; Kaefer, I. 2020. Four new anuran defense behaviors observed in the cane toad Rhinella marina. Ethology Ecology \& Evolution. https://doi.org/10.1080/03949370.2020 .1769737
Gonçalves M.W.; Gambale P.G.; Godoy F.R.; Alves A.A.; Rezende P.H.A.; Cruz A.D.; et al. 2017. The agricultural impact of pesticides on Physalaemus cuvieri tadpoles (Amphibia: Anura) ascertained by comet assay. Zoologia, 34: e19865.

Haas, S.E.; Reeves, M.K.; Pinkney, A.E.; Johnson, P.T.J. 2017. Continental-extent patterns in amphibian malformations linked to parasites, chemical contaminants, and their interactions. Global Change Biology, 24: e275-e288.

Koleska, D.; Jablonski, D. 2016. Two cases of unclear hindlimb malformation in Bombina variegate. Ecologica Montenegrina, 9: 56-58.

Lannoo, M. 2008. Malformed Frogs: The Collapse of Aquatic Ecosystems. University of California Press, Berkeley. 288p.

Mônico, A.T.; Silva-Soares, T.; Koch, E.D. 2019. Malformation in three anuran species from a preserved remnant of Atlantic Forest in southeastern Brazil. Neotropical Biology and Conservation, 14: 213-220.

Moraes, L.J.C.L.; Pavan, D.; Barros, M.C.; Ribas, C.C. 2016. The combined influence of riverine barriers and flooding gradients on biogeographical patterns for amphibians and squamates in south eastern Amazonia. Journal of Biogeography, 43: 2113-2124.

Orton, F.; Routledge, E. 2011. Agricultural intensity in ovo affects growth, metamorphic development and sexual differentiation in the common toad (Bufo bufo). Ecotoxicology, 20: 901-911.

Ouellet, M.; Bonin, J.; Rodrigue, J.; Desgranges, J.L.; Lair, S. 1997. Hindlimb deformities (ectromelia, ectrodactyly) in free-living anurans from agricultural habitats. Journal of Wildlife Diseases, 33: 95-104.

Schiesari, L.; Grillitsch, B. 2011. Pesticides meet megadiversity in the expansion of biofuel crops. Frontiers in Ecology and the Environment, 9: 215-221.

Schiesari, L.; Waichman, A.; Brock, T.; Adams, C.; Grillitsch, B. 2013. Pesticide use and biodiversity conservation in the Amazonian agricultural frontier. Philosophical Transactions of the Royal Society, Biological Sciences, 368: 20120378.

Wagner, N.; Reichenbecher, W.; Teichmann, H.; Tappeser, B.; Lötters E. 2013. Questions concerning the potential impact of Glyphosate-based herbicides on amphibians. Environmental Toxicology and Chemistry, 32: 1688-1700.

Wells, K.D. 2007. The Ecology and Behavior of Amphibians. University of Chicago Press, Chicago. 1148p.

RECEIVED: $26 / 02 / 2020$

ACCEPTED: $27 / 08 / 2020$

ASSOCIATE EDITOR: Carlos J. Sousa Passos 